\title{
China-U.S.-Europe Relations: Shaping a Future-Oriented World Order
}

\author{
Wu Chunsi
}

\begin{abstract}
China, Europe, and the United States constitute a very important trilateral relationship in China's diplomacy. This trilateral relationship is incomparable to that of China, the United States, and the Soviet Union during the Cold War not only in that "polar" is no longer a valid concept to describe major-power relations today, but also in that China-U.S.Europe relations are not deliberately constructed for the three parties to balance each other or oppose any party. To be more specific, China's deliberations on Europe's role in the world have gone beyond the logic of balance of power. Especially after the 2008 global financial crisis, China has taken ever more efforts to strengthen its ties with European nations, both to meet its growing economic demands, and because it seeks to learn from the post-modern social governance experience in Europe. In comparison, China's relationship with the United States is far more complex as the two countries have been engaged in increasing divergence and competition not only on specific issues, but more importantly, in trends of the world order. As three giants that have the potential to lead the world to a better future,
\end{abstract}

Wu Chunsi is Senior Fellow and Director of the Institute of International Strategic Studies, Shanghai Institutes for International Studies (SIIS). Her mailing address is 195-15 Tianlin Road, Shanghai 200233, China. She can also be reached at wuchunsi@siis. org.cn.

(C) 2016 World Century Publishing Corporation and Shanghai Institutes for International Studies China Quarterly of International Strategic Studies, Vol. 2, No. 4, 449-464

DOI: $10.1142 / \mathrm{S} 2377740016500305$ 
China, Europe, and the United States need to deepen their mutual understanding and foster greater consensus about the future world order through closer communication and exchange, as well as enhanced cooperation on global governance.

Keywords: China-U.S.-Europe relationship; major-power relations; world order; global governance.

\section{China-U.S.-Europe Relations: A Brief Overview}

When talking about trilateral relations, people tend to recall the strategic triangle among China, the United States, and the Soviet Union during the Cold War, which greatly influenced the power dynamics of the time and in large part determined the general trends of world politics. Since the end of the Cold War, however, the international environment for major-power relations has undergone substantial changes. Today, it would be misleading to continue to use "triangle" as a parameter in observing major-power relations in the world.

Indeed, with the lasting rise of developing nations, especially emerging economies represented by the BRICS (Brazil, Russia, India, China and South Africa), democratization of international relations has grown to be a dominant trend of world politics since the end of the Cold War, and the concept of "polar" is of little, if any, relevance to the ever more globalized world. Although major powers still play a leading role in the world arena, the relationships among them are quite different from the U.S.-Soviet relationship in the Cold War era when both giants regarded each other as an adversary and strove for each other's demise. Rather, major powers today constitute multiple "power centers" that are closely connected to and interdependent on each other. ${ }^{1}$ Thus, it would be outdated to overemphasize those traditional concepts in geopolitical studies such as checks and balances among different "polars."

As three biggest economies in the world, China, Europe, and the United States have come to forge a robust trilateral relationship, though its

${ }^{1}$ For the discussion of polarity, see Richard N. Haass, “The Age of Nonpolarity: What Will Follow U.S. Dominance," Foreign Affairs, Vol. 87, No. 3 (May/June 2008). 
strategic significance to the world order is not as huge or conspicuous as the China-U.S.-Soviet triangle during the Cold War. This is because the traditionally dominating role of nation-states in world affairs is now shared by an increasing number of non-state actors like transnational enterprises and non-governmental organizations. Besides, with the democratization of international relations, medium-sized and small nations can speak with louder voices on the world stage. As a matter of fact, even during the Cold War, policies of major powers were under constant influence of much smaller countries. ${ }^{2}$ Therefore, it would be absurd to expect China, Europe and the United States to dominate the global agenda or determine the trends of international relations today.

Also, one cannot say that the trilateral relationship among China, Europe, and the United States weighs heavier than the trilateral relationship among China, the U.S. and Russia or that among China, the U.S. and Japan. In fact, the China-Europe-U.S. relationship is only one of the many minilateral relations ${ }^{3}$ in world politics. In comparison, the strategic triangle among China, the U.S. and the Soviet Union during the Cold War was quite unique not only in that there was no other comparable trilateral relationship at the time, but also in that it carried far more ideological significance than other trilateral relationships in history. To some extent, the China-U.S.Soviet triangle was carefully designed by political leaders of the time, especially then U.S. President Richard Nixon and Chinese leader Mao Zedong, to balance against each other. The China-Europe-U.S. relationship today, however, is not targeted at any party within or outside the relationship. Thus it would be unrealistic for any party to use the trilateral relationship to prevail over others.

Indeed, the China-Europe-U.S. relationship needs to be observed from a different perspective. China has been enhancing its ties with Europe since

${ }^{2}$ For a vivid description of how the U.S.' Middle East policy was shaped by much smaller nations such as Egypt, Israel and Jordan in the 1970s, see Henry A. Kissinger, Years of Renewal: The Concluding Volume of His Memoirs (New York, NY: Simon \& Schuster, 1999), Part Four.

${ }^{3}$ Mini-lateralism is a new concept that has received much academic attention in recent years. For the discussion of mini-lateral diplomacy in China's foreign strategy, see Wang Fan, "Zhongguo Waijiao Zhanlue Guannian de Zhuanbian [Conceptual Changes in China's Diplomatic Strategy]," Contemporary World, No. 2 (February 2014). 
the 2008 financial crisis, yet economic and geopolitical considerations can at most partly explain China's growing enthusiasm, for Europe is still suffering from recurring recession and financial challenges, as well as growing discord about many salient issues. It is rather the post-modern features of Europe that are most appealing to China, which believes that closer ChinaEurope-U.S. coordination will facilitate exchange and cooperation among modernizing and post-modern societies. With enhanced joint efforts with Europe and the United States, China aims to contribute more to the repair and upgrade of the international institutions damaged in the 2008 financial crisis, and work with the international community to foster a futureoriented world order.

\section{China's Closer Embrace of Europe Since 2008}

In the aftermath of the 2008 global financial crisis, people were surprised to find China enhancing its diplomatic ties with Europe, even though Europe suffered even more than the United States at the peak of the crisis. As Table 1 shows, compared with their engagement with the United States, Chinese leaders have paid many more visits to Europe and kept closer contacts with European leaders since 2008.

It is important to note that the statistics could be misleading for understanding China's diplomatic engagement with other major powers. First, overseas visits by Chinese leaders are usually accompanied by multilateral summit meetings, and their visits to Europe and to the United States are no exceptions. Next, Chinese leaders' visits to Russia, a "special" and salient Eurasian power, are excluded from the table. Furthermore, the China-U.S. Strategic and Economic Dialogue (S\&ED), previously called the Strategic Economic Dialogue (SED) during the G. W. Bush administration, is not included in the table - for all the importance the S\&ED represents to China-U.S. relations, top Chinese leaders have never visited the United States for that purpose. Finally, China's leaders' meetings with U.S. and European leaders on other international occasions are not included in Table 1 either.

Nevertheless, Table 1 does indicate that communications between Chinese and European leaders during the past eight years have been closer than that between Chinese and U.S. leaders. The number of visits may not 
Table 1. Visits of Chinese Presidents and Premiers to the U.S. and Europe (2009-2015)

\begin{tabular}{|c|c|c|}
\hline Year & To the United States & To European Countries \\
\hline 2009 & None & $\begin{array}{l}\text { February: State visits to Switzerland, } \\
\text { Germany, Spain, Britain, and EU } \\
\text { Headquarters (Premier Wen } \\
\text { Jiabao) } \\
\text { June: State visits to Croatia and } \\
\text { Slovenia (President Hu Jintao) } \\
\text { July: State visit to Italy (President } \\
\text { Hu) }\end{array}$ \\
\hline 2010 & $\begin{array}{l}\text { April: Nuclear Security } \\
\text { Summit (President Hu } \\
\text { Jintao) }\end{array}$ & $\begin{array}{l}\text { October: State visits to Greece, } \\
\text { Belgium and Italy (Premier Wen) } \\
\text { October: State visits to France and } \\
\text { Portugal (President } \mathrm{Hu} \text { ) }\end{array}$ \\
\hline 2011 & $\begin{array}{l}\text { January: State visit } \\
\text { (President } \mathrm{Hu} \text { ) }\end{array}$ & $\begin{array}{l}\text { June: State visits to Hungary, Britain } \\
\text { and Germany (Premier Wen) }\end{array}$ \\
\hline 2012 & None & $\begin{array}{l}\text { April: State visits to Iceland, Sweden } \\
\text { and Poland (Premier Wen) } \\
\text { June: State visit to Denmark } \\
\text { (President Hu) } \\
\text { September: State visit to Belgium } \\
\text { (Premier Wen) }\end{array}$ \\
\hline 2013 & $\begin{array}{l}\text { June: Sunnylands Summit } \\
\text { meeting (President Xi } \\
\text { Jinping) }\end{array}$ & $\begin{array}{l}\text { November: State visit to Romania } \\
\quad \text { (Premier Li Keqiang) }\end{array}$ \\
\hline 2014 & None & $\begin{array}{l}\text { March: State visits to the Nether- } \\
\text { lands, France, Germany, Belgium, } \\
\text { and EU Headquarters (President } \\
\text { Xi Jinping) } \\
\text { June: State visits to Britain and } \\
\text { Greece (Premier Li) } \\
\text { October: State visits to Germany and } \\
\text { Italy (Premier Li) } \\
\text { December: State visit to Serbia } \\
\text { (Premier Li) }\end{array}$ \\
\hline 2015 & $\begin{array}{l}\text { September: State visit } \\
\quad \text { (President } \mathrm{Xi} \text { ) }\end{array}$ & $\begin{array}{l}\text { January: State visit to Switzerland } \\
\text { (Premier Li) } \\
\text { June: State visits to Belgium and } \\
\text { France (Premier Li) } \\
\text { October: State visit to Britain } \\
\text { (President } \mathrm{Xi} \text { ) }\end{array}$ \\
\hline
\end{tabular}

Source: Compiled by the author based on information retrieved from the website of the Ministry of Foreign Affairs of China. 
explain everything, but at least it suggests that the China-Europe relationship has grown to be at a level comparable to that between China and the United States, which is widely regarded as the most important bilateral relationship in the world.

Other than its growing need to expand economic and trade relations with Europe, China has been strengthening its relationship with Europe since 2008 mainly for two other reasons: one is the diminishing charm of the U.S. development model, or the "Washington Consensus," to China; and the other is that China has found the European way of development increasingly relevant to its own path.

The 2008 financial crisis has greatly shattered the long-held theories and beliefs of the

China has been enhancing its ties with Europe mainly to learn from its experience in modernization and post-modern development. world on sustainable development, and an important lesson China has learned is that the "Washington Consensus" on neo-liberalist approaches to development is flawed in both political and economic aspects. In the first place, the financial crisis originated in the United States, which proves that industrial hollowing-out and overly pursued virtual economy can generate unexpectedly negative consequences. Second, China has come to realize that it should always remain vigilant to the influence of the consumer culture of the United States. During the crisis, the large savings of Chinese residents proved to be an advantage for the Chinese economy. It is hopeful that such experience will make China more prudent in adopting the consumer culture prevailing in the United States for decades. Third, with a much larger population and scant natural resources, China's natural endowments for economic development are far worse than those of the United States. Thus China cannot and should not follow the U.S. way of extravagant consumption of energy and resources, not least because the Chinese government is committed to leading the whole population in building a prosperous and harmonious society for all under the two "Centennial Goals."

Alarmed by the financial crisis, China began to reconsider the direction of its economic development, and the European experience in 
modernization and post-modern development caught China's attention. ${ }^{4}$ During the crisis, Germany maintained strong economic performance, which was a rare case in the developed world. The success story of Germany indicates that it is possible to develop in a way different from the United States, that the manufacturing industry should be regarded as the core competitiveness of a country in the process of modernization, and even for its post-modern development. Besides, Europe's strong advocacy for environmental protection is also very relevant to China's development today. Since the early 21 st century, China has been trying to upgrade its way of economic development, stressing more on a growth of high quality rather than mere quantity. With China's increasing emphasis on sustainable development and ecological civilization, it is quite understandable for China to reach out to Europe for experience and expertise in these regards, especially in environmental issues.

As a matter of fact, China's early engagement with Europe in environmental issues generated more conflicts than cooperation. A typical example is the dispute between China and some European countries on the issue of climate change in 2009. When China was determined to play a more active role on the issue of climate change, it began to work more closely with the Obama administration, largely leaving European countries aside, and thus causing much grievance and criticism from Europe. Yet in the long run, since Europe is a resolute supporter of conventions on climate change and environmental protection, more productive dialogues can be expected between China and Europe.

Indeed, how to balance economic development and environmental protection has become a major factor drawing China closer to Europe in the past years, while enhancing economic ties is another reason for the growing number of visits made by Chinese leaders. Since 2008, China has not only strengthened its cooperation with traditional major European economies like Britain, France, and Germany, but it has also been active in exploring new platforms for cooperation with other European countries. The " $16+1$ "

${ }^{4}$ For the bigger part of modern history, Europe had been a major source of experience and expertise for China to learn from. It was only after the 1980s that the U.S. influence on China's society and development began to surpass that of Europe. 
cooperation, a new cooperative mechanism between China and 16 Central and Eastern European countries established in $2012,{ }^{5}$ is a case in point.

\section{China-Europe Relations: Beyond Geopolitical Considerations}

Since the 1970s, China has revised its understanding of Europe's role in world politics several times. At first, it looked at the role of Europe in light of the balance of power at the time. For example, in the "Three-World Theory" proposed by Chairman Mao, Europe was regarded as a part of the Second World, which was not only a buffer zone between the United States and the Soviet Union, the two superpowers in the First World, but also stood between the First World and the Third World of developing countries. Even after the end of the Cold War, the balance-of-power theory concerning Europe's role remained popular for well over a decade, reflected in the concept of multi-polarization of world politics. According to this theory, as a "polar" of the world, Europe could check against the U.S. hegemony to some extent. Such hypothesis seemed to be proved valid in 2003, when France and Germany opposed the U.S. invasion of Iraq. However, China soon found that Europe's position in world politics was much more complicated than previously assumed. The ChinaEurope relationship has experienced many ups and downs since then.

In 2003, the European Union released a policy document on its relations with China, defining the bilateral relationship as a strategic partnership. ${ }^{6}$ Yet in practice, China-Europe relations soon encountered major setbacks. The first setback was the disenchanting out-

China is committed to fostering a closer comprehensive partnership with Europe against all odds. comes of several key issues embodying their

\footnotetext{
${ }^{5}$ Regarding China's cooperation with Central and Eastern European countries under the " $16+1$ " framework, some observers in Western Europe still have their reservations. See Long Jing: "Relations between China and CEE Countries: Development, Challenges and Recommendations," China International Studies, No. 5 (September/October 2014), pp. 37-50.

${ }^{6}$ Commission of the European Communities, EU Commission Policy Paper: A Mature Partnership-Shared Interests and Challenges in EU-China Relations(Brussels: Commission of the European Communities, 2003), http://eur-lex.europa.eu/legal-content/EN/TXT/PDF/? uri=CELEX:52003DC0533\&from $=$ EN.
} 
strategic partnership. One was the lifting of Europe's arms embargo on China. Although some major European countries did intend to do so according to China's request, the intention failed to translate into action due to vehement U.S. opposition. ${ }^{7}$ The other was China's futile attempt to participate in Europe's satellite navigation system Galileo. Cooperation in outer space could serve as a shining symbol of strategic cooperation, but unfortunately, China-Europe cooperation in this regard also failed, and China had to leave the Galileo project in 2008 and start to develop its own navigation satellite system Beidou.

In addition to the difficulties in strategic cooperation, China and European countries are also confronted by disputes in ideological arenas. Some European countries are intent on reiterating the importance of human rights issues on their policy agenda concerning China, ${ }^{8}$ which, due to their different understanding of the concept and priority-setting of their agendas, has worsened the political atmosphere for overall cooperation between China and Europe. Even worse, leaders of some major European countries openly received the Dalai Lama despite strong opposition from the Chinese government, and the torch relays for the 2008 Beijing Olympics were seriously disrupted in London and Paris - bringing much shock and a feeling of insult to China's strategic circle and the public alike.

Economic cooperation between China and European countries has often encountered difficulties as well. Since China established diplomatic relations with the European Communities, the predecessor of the European Union, in 1975, their bilateral trade and economic relationship has developed rapidly. In its 2003 policy document on China, the EU gave a very positive assessment of China's economic potential, indicating its high expectations for economic cooperation with China. Yet the optimistic tone began to change only three years later - in a policy document published in 2006, the EU declared at the beginning of the Executive Summary that

${ }^{7}$ Zhao Huaipu, "Dangqian Zhongou Guanxi Qianxi [An Analysis of the Current State of the China-EU Relationship]," Foreign Affairs Review, No. 5 (October 2008), pp. 20-21.

${ }^{8}$ Chen Zhimin, Dai Bingran et al., "Zhongguo zai Zhongou Guanxi Zhong de Zhongdian ji Zhanlue [China's Priorities and Strategy for China-EU Relations]," Pacific Journal, Vol. 20, No. 10 (October 2012), p. 31. 
"China is the single most important challenge for EU trade policy."" Afterwards, the EU began to look at China as an economic competitor and thus tightened its economic policies toward China, such as strengthening intellectual rights protection, bringing China more often to the dispute mechanism under the World Trade Organization (WTO), and exercising anti-dumping and anti-subsidy actions against Chinese exports, among others.

While China and Europe have encountered more problems in cooperation, the United States and the EU have overcome their disputes in 2003 and restored their traditional companionship. ${ }^{10}$ Seeing the shifts of the China-Europe relationship as compared with the U.S.-Europe relationship, Chinese scholars and policy-makers have been more realistic about the relationship among China, Europe, and the United States. Given the cultural and ideological similarities between Europe and the United States, it is unimaginable that Europe would stand with China in a geopolitical competition with the United States, and thus China has remained prudent in adding geopolitical issues to its agenda of cooperation with Europe, but has focused on "lower-politics" issues like financial, trade, cultural and peopleto-people cooperation.

\section{China-U.S. Competition for the Future World Order}

Admittedly, China-U.S. relations are full of misperceptions, misunderstandings, contradictory messages, and misleading interpretations. In retrospect, the current tension between China and the United States began in late 2009 and early 2010, when the two countries engaged in growing disputes on issues ranging from climate change, trade, to Taiwan, the Dalai Lama, and security incidents in the Asia-Pacific. Nevertheless, keen observers noticed that in this round of disputes, the significance of such

${ }^{9}$ Commission of the European Communities, EU Commission Working Document: Closer Partners, Growing Responsibilities - A Policy Paper on EU-China Trade and Investment: Competition and Partnership (Brussels: Commission of the European Communities, 2006), p. 3, http://aei.pitt.edu/38108/1/COM_(2006)_632.pdf.

${ }^{10}$ U.S. President George W. Bush visited EU headquarters in February 2005. As to the adjustment of U.S.-EU relations, see Zhao Huaipu, "Dangqian Meiou Guanxi: Daqushi yu Xinbianhua [Current U.S.-EU Relations: Major Trends and New Changes]," Contemporary International Relations, No. 2 (February 2008), pp. 40-46. 
traditional issues as Taiwan, trade, and human rights was waning, while new issues related to regional security and future Asia-Pacific order was on the rise, because China's global status was suddenly boosted by the 2008 global financial crisis. In fact, some observers have begun to use the world's "No. 1" and "No. 2" to refer to the United States and China since China surpassed Japan in terms of nominal GDP and became the second largest economy in $2010 .^{11}$

Calling the United States and China "No. 1" and "No. 2" is convenient for the general audience to quickly grasp the nature of the current ChinaU.S. relationship; hence its popularity in the international and Chinese public media. However, it has caused much confusion and misinterpretation in actual practice of China-U.S. relations - at least from the Chinese perspective, replacing the United States or any other country as a new "No. 1 " is not China's objective. Rather, it is continued improvement of the livelihoods of the Chinese people that lies at the core of China's long-term development. It is true that after three decades of rapid economic growth, the Chinese people enjoy a better quality of life today, yet China is still facing daunting challenges on its path of development, even when it is already the second-largest economy in the world.

Admittedly, the Chinese economy developed in a relatively unbalanced way: in general, people who live in eastern, coastal regions and in big cities enjoy relatively modern and comfortable lives, while those living in remote, mountainous, and rural areas are much worse-off, unable to enjoy the benefits of China's rapid economic growth. Therefore, as former Chinese President $\mathrm{Hu}$ Jintao pointed out in his Report to the 18th National Congress of the Communist Party of China (CPC) in November 2012,

We must be soberly aware that China is still in the primary stage of socialism and will long remain so. This basic condition of China has not changed; nor has the principal problem in our society, that is, how we can meet the ever growing material and cultural needs of the people with backward social production; nor has China's international position as the largest developing country in the world... We must adhere to the central task,

${ }^{11}$ Yuan Peng, "Meizhong yao Shiying Laoda yu Laoer Guanxi [The United States and China Must Adapt to the Relationship between No. 1 and No. 2]," Global Times, May 24, 2010. 
economic development, and the two basic points - the Four Cardinal Principles and the policy of reform and opening up in our great endeavor to develop socialism with Chinese characteristics. $^{12}$

This means that in China's future development, the existing interest structure must be readjusted and the benefits of China's reform and opening-up more evenly and fairly distributed - another reason why China has been focusing on domestic issues in its development strategy.

In addition, the Chinese government has recognized over the past decade that it has to transform its basic economic structure to facilitate further growth. The high costs of energy consumption and environmental damage cannot be accepted any more. To achieve more sustainable development, China's new economic structure must be environmentally friendly.

It is clear that developing the economy and improving people's living conditions will remain the priority of the Chinese government, rather than replacing the United States as a new dominant power. Competition between China and the United States, however comprehensive or intense it may turn out to be, must be assessed in this broad context.

As a matter of fact, China and the United States do need each other and have cooperated on an increasing number of issues. It is true that after the 2008 financial crisis, economic interactions between both countries encountered some problems, for the previous model of economic cooperation - in which the United States largely played the role of a consumer and China the role of a manufacturer - was no longer sustainable. However, their economic cooperation has been ever more strengthened. For example, both coun-

Despite growing competition, China and the U.S. share more common interests in managing bilateral disputes and tackling global challenges. tries work closely together not only on the

${ }^{12}$ For the full text of President Hu's Report at the 18th Party Congress, see China Daily, November 19, 2012, http://language.chinadaily.com.cn/news/2012-11/19/content_15941774. htm. 
Group of Twenty (G20) platform to deal with the negative repercussions of the 2008 financial crisis, but also on such issues as exploring alternative energy resources and looking for new growth points for world economy. Besides, they have carried out extensive dialogues on economic and financial issues under S\&ED and other bilateral mechanisms.

Apart from economic cooperation, China and the United States have also cooperated effectively in addressing global or transnational challenges. One of the landmarks is their bilateral accord on climate change. Without relentless efforts from both countries, the Paris Agreement could not have been reached in April 2016. Another area of close cooperation between China and the United States is nuclear security. When U.S. President Obama initiated the idea of holding regular nuclear security summits (NSS) in 2010, China warmly extended its recognition and support. Chinese leaders attended all the four summits (in 2010, 2012, 2014 and 2016 respectively), and a Nuclear Security Center of Excellence, financed by both countries, has been established in Beijing. In addition, both countries have been cooperating extensively on such global issues as anti-terrorism, fighting Ebola, supporting development in Africa, and handling the Iran nuclear issue, to name but a few.

Even when major bilateral disputes occurred, China and the United States have managed to settle them in a fairly cordial and effective way. Top leaders of both countries meet routinely and the institutionalized S\&ED, participated by a number of key ministers from each country, is also very helpful to ease their tensions on most salient issues. With a cooperative spirit, both countries have confined their disputes to a moderate level, such as those on the South China Sea and cyber security. The two countries' militaries also increased their engagement, albeit with occasional interruptions, and signed a few codes of conduct on unexpected encounters in the sea and air. Thus, cooperation, coordination, and compromise still prevail in China-U.S. relations; the interactions between the established superpower and the emerging power prove far more complicated than mere competition.

Undoubtedly, China and the United States have been engaged in more intense strategic competition in recent years. But few people in Beijing and Washington believe that the two countries are expecting strategic confrontation, let alone a war, to happen any time soon. For now, their competition is mostly observed in the so-called "strategic global commons," 
such as the high seas, cyberspace, and outer space. ${ }^{13}$ From this perspective, one can say that China-U.S. strategic competition is not about those tangible issues today, but about future leadership on global issues.

Global commons, in its literal sense, refer to the areas that all countries have the rights to get access to. However, for quite a long period of time, the United States, with its advanced technology and strong economic capacity, almost monopolized those areas. The situation has changed slowly with the rise of other powers on the world stage, especially China. Over the past decade, China has increasingly engaged itself in all domains of the strategic global commons, challenging the past monopoly of the United States over them. To maintain and consolidate its monopoly, the United States has taken numerous efforts to constrain China's activities to a limited scope under the name of "regulating Chinese behavior." With the continuing rise of China and closer communication and cooperation between China and the United States, however, it is expected that they will work with the international community to develop a new set of norms for behavior in such domains of strategic global commons to better reflect and serve the future world order.

\section{China-U.S.-Europe Relationship in Future Perspective}

China, Europe, and the United States, as three powers with substantial capacity to influence the course of world affairs, must enhance their communication and cooperation more on future-oriented issues, for without their committed participation it would be difficult to achieve any substantial progress on the salient global issues the world is facing today and in the future. ${ }^{14}$ The United States, Europe, and China represent different ways of development. Though the United States and Europe share similar values and cultural origins, the former upholds free market principles and takes a very skeptical stance toward the government's role in economic affairs,

${ }^{13}$ For more detailed analysis on China-U.S. relations in strategic global commons, see Wu Chunsi, “Meiguo de Quanqiu Zhanlue Gongyu Jiaolu ji Zhongguo de Yingdui [U.S. Concerns over Global Commons and China's Policies]," Global Review, No. 6 (2014), pp. 90-104.

${ }^{14}$ Bo Yan, “Quanqiu Qihou Bianhua Wenti shang de Zhongmeiou Sanbian Guanxi [ChinaU.S.-Europe Trilateral Relations on the Issue of Climate Change]," Contemporary International Relations, No. 4 (April 2010), pp. 15-20. 
while the latter is more enthusiastic about social democracy in governance; on the issue of national sovereignty, Europe's attitude is even more flexible than that of the United States. In comparison, China represents a civilization whose echos are easily found in East Asian countries and the vast developing world. Strengthening communication and cooperation among the United States, Europe, and China has become absolutely necessary, for only through mutual understanding and mutual learning can they jointly develop viable options for the world. As it is, working toward a better world has been on top of their global agendas, where they share increasing common interests and are faced by the same global challenges. The question is how to promote their communication and cooperation so that they can work together to generate more benefits for the world.

To combine the goals of shaping the

China-Europe-U.S. cooperation should focus on global governance issues to shape the future world order. future world order and effectively handling contemporary challenges, China, Europe and the United States need to focus on global governance issues mainly in three specific areas:

The first is global economic governance. It has been eight years since the outbreak of the financial crisis in 2008. Many measures have been proposed and taken by the international community, but their effectiveness seems to be limited. The world economy has yet to show strong recovery, and at present, many countries are still trapped in serious economic and debt crises. In this gloomy environment, economic protectionism is on the rise, and exclusive economic blocs have begun to emerge. Other than the G20 and other global platforms for economic governance, China, Europe and the United States should assume more responsibilities in providing the world with a commonly beneficial and more guaranteed economic blueprint with more coordination on their plans in trade, investment and other economic issues, so as to explore ways to make international economic institutions more accommodative; separating the world economy into competing blocs will eventually harm everyone.

Next, China, Europe, and the United States should work more closely to tackle transnational threats and challenges. It has become a cliché that major powers should strengthen cooperation on global affairs, especially 
when their willingness to invest in external affairs is decreasing. In the 2016 U.S. presidential election, both candidates showed their reluctance to take on more global responsibilities. After the Obama administration's global agenda to address climate change and nuclear security, no statement has been made by the President-elect, Mr. Trump, on his global agenda. Instead, he emphasizes on the only goal to "Make America Great Again," even at the expense of the rest of the world. Such a passive attitude may bring very negative consequences, as increasing transnational threats can permeate any "wall" a country builds around itself. It is time that all major powers of the world sat together and worked out a joint framework to tackle those threats in a sustainable and effective way.

Finally, China, Europe, and the United States should take the lead in better management of the global strategic commons. Not only do they possess the necessary technology, great capacity and sound development plans, but they also tend to hold an open attitude toward cooperation in these fields. Thus their dialogue on making norms and rules in the global strategic commons may prove a valuable initial step for the international community to follow suit. Given the high sensitivity of the issue and the lack of foundation for inter-governmental dialogue, it would be workable for them to start from institutional dialogue among experts and scholars.

In conclusion, the China-Europe-U.S. relationship is a very important trilateral relationship in world politics today, which should not be regarded as a strategic triangle similar to that among China, the United States, and the Soviet Union in the Cold War era, but a potential platform to shape a better order for the future of humanity. 